\title{
Efficacy of Wild Medicinal Plant Extracts Against Predominant Seed-Borne Fungi of Broad Bean Cultivars
}

\author{
Z. A. M. BAKA* \\ Department of Botany, Faculty of Science, Damietta University, New Damietta, Egypt
}

(Received: 16 June 2014; accepted: 17 July 2014)

\begin{abstract}
Seed samples of four Egyptian broad bean cultivars were tested for seed-borne fungi. The deep freezing method was used to isolate twelve seed-borne fungi viz., Alternaria alternata, Aspergillus flavus, A. niger, Botrytis fabae, Cladosporium cladosporioides, Fusarium oxysporum, F. solani, Penicillium italicum, Rhizoctonia solani, Rhizopus stolonifer, Stemphylium globuliferum and Trichothecium roseum from the broad bean cultivars viz., Giza 3, Giza 429, Giza 843 and Misr 1. Aspergillus flavus, Botrytis fabae, Fusarium oxysporum and Penicillium italicum were the most predominant fungal species. Aqueous extracts from five wild medicinal plants (Asclepias sinaica, Farsetia aegyptia, Hypericum sinaicum, Phagnalon sinaicum, and Salvia aegyptiaca) which were collected from the Sinai Peninsula, Egypt were tested against the predominant fungal pathogens. All the aqueous plant extracts significantly inhibited the mycelial growth of these fungi, but the extract of Asclepias sinaica exhibited the strongest antifungal activity. The maximum seed germination rate was observed in infested Giza 843 and minimum in Misr 1. Treating seeds with plant extract of Asclepias sinaica (10\%) enhanced the percentage of seed germination of all cultivars in both laboratory and pot experiments. Maximum root and shoot lengths of seedlings were recorded in Giza 843 during fungal infestation or treatment by plant extract. In greenhouse experiment, the aqueous A. sinaica extract reduced disease severity and total pigments but increased total phenolics and fruit yield.
\end{abstract}

Keywords: antifungal activity, Egypt, plant extracts, seed-borne fungi, broad bean cultivars.

Faba bean (Vicia faba L.) is a food and feed legume of great socio-economic importance and is one of the earliest domesticated food legumes in the world, probably in the late Neolithic period. Faba bean ranks sixth in production among the legumes grown in the world. China has been the main producing country, followed by Ethiopia, Egypt, Italy, and Morocco (Salunkhe and Kadam, 1989).

Faba bean is the most important leguminous crop used for human nutrition in Egypt. Faba bean is an excellent source of protein, calcium, phosphorus, lysine, methionine, cystein, crabohydrates, dietary fibers, choline, lecithin, and minerals (Wang et al., 2014).

All stages of faba bean growth are subjected to numerous injuries and stresses that affect their growth and development. There are many seed-borne fungi, while a number are serious pathogens on flowers and maturing seeds. These pathogens reduce the yield of seed both qualitatively and quantitatively. Other fungi, including saprophytes and very

\footnotetext{
*E-mail: zakariabaka52@gmail.com
} 
weak parasites, may lower the quality of seeds. Many fungal pathogens were isolated from faba bean seeds such as Alternaria spp., Ascophyta fabae, Aspergillus spp., Botrytis cinerea, B. fabae, Cephalosporium sp., Cladosporium sp., Epicoccum sp., Fusarium spp., Mucor sp., Penicillium spp., Rhizoctonia sp., Rhizopus sp., Stemphylium sp., Trichothecium sp., and Verticillium sp. (Neergard, 1979; Abdel-Hafez, 1988; El-Wakil et al., 2009). Seed abortion, shrunken seeds, reduction of seed size, seed rot, seed necrosis, seed discoloration, reduction in germination capacity and physiological alterations in seed are the symptoms caused by these pathogens (Neergard, 1979). Moreover, seeds of broad bean can be contaminated by mycotoxins secreted by some fungi growing on these seeds. Mycotoxins attract worldwide attention because of the significant economic losses associated with their impact on human health, animal productivity and trade (Khlangwiset et al., 2011).

Management of plant diseases is important for most crops, and it is particularly critical for the production of high-quality seeds. Plant pathogens can reduce the quantity and quality of the seed harvested, and in addition they can be preserved in seed lots in the case of seedborne pathogens. In this way, seeds can inadvertently provide an efficient means of plant pathogen dissemination (Mancini and Romanazzi, 2014).

Attempts have been made to reduce seed-borne fungi by chemical treatment of the seeds and some successes have been reported. Seed dressings are used to eliminate most surface infestation of seeds but have relatively little effect on internally borne organisms (Jackson, 1963). However, the application of these fungicides may not always be desirable, owing to their toxic effects on non-target organisms (Pal and Gardener, 2006).

An urgent need for alternatives to fungicides for the control of seed-borne fungi are important in recent years, much attention has been given to non-chemical systems for seed treatment to protect them against seed-borne pathogens. Plant extracts have played a significant role in the inhibition of seed-borne pathogens and in the improvement of seed quality and field emergence of plant seeds. Many authors reported the effective and safe use of plant extracts for controlling seed-borne fungi (El-Metwally et al., 2010; Yoon et al., 2011; Ammar et al., 2013; Perello et al., 2013; Baka 2014b).

This work was designed to evaluate the efficacy of wild medicinal plant extracts on the predominant fungi isolated from different Egyptian broad bean cultivars. The effect of these extracts on seed germination, seedling vigor, disease severity, photosynthetic pigments, total phenolics and fruit yield was also evaluated.

\section{Materials and Methods}

\section{Laboratory experiments \\ Isolation of fungi from seed samples}

Seed samples of 4 Egyptian cultivars (Giza 3, Giza 429, Giza 843 and Misr 1) of Vicia faba L.were collected from different markets where the markets were known to be one of the main sources of planting seeds of different cultivars. One kilogram of primary sample was taken from each selected market. The seed samples were labelled and put in 
plastic bags and tightly sealed and stored at room temperature $\left(25^{\circ} \mathrm{C}\right)$ in transit. Seed samples were then stored in a cold room of 10 to $15^{\circ} \mathrm{C}$ at the Botany Department, Faculty of Science, Damietta University, Egypt for good preservation prior to seed health analysis and treatment. The seed samples were analysed using the Deep-freeze blotter method (Mathur and Kongsdal, 2003). The design for the analysis was Completely Randomized Design (CRD). A set of three blotter papers were dipped in distilled water and placed in Petri dish (90 mm diameter). The seeds were poured into a tray and samples for plating taken at random using the spoon method as described by Mathur and Kongsdal (2003). Ten seeds per dish were plated using a pair of forceps. Hundred seeds per replicate were used for each sample. The plated seeds were incubated at a temperature of $22{ }^{\circ} \mathrm{C}$ for 7 days in alternating cycles of 12 hours darkness and 12 hours light. However, the plated seeds were kept in a deep-freezer after 24 hours of incubation for 12 hours of freezing at a temperature of $-20{ }^{\circ} \mathrm{C}$ after which incubation was continued. The source of light used in the incubation room was near ultraviolet (NUV).

After incubation, the growth characters as well as percentage of infection were recorded. The fungi were maintained on Potato Dextrose Agar (PDA) medium and identified after reference to Booth (1971); Barnett and Hunter (1972); Raper and Fennell (1977) and the Regional Mycological Center at Azhar University, Egypt.

\section{Plant materials and extract preparation}

Five wild medicinal plants (Asclepias sinaica, Farsetia aegyptia, Hypericum sinaicum, Phagnalon sinaicum, and Salvia aegyptiaca) were collected from different locations of the Sinai Peninsula, Egypt and used in this study (Table 1). The aerial parts of these plants were extracted using water. For extraction, $100 \mathrm{~g}$ of each air-dried medicinal plant material were separately added to $1000 \mathrm{~mL}$ of distilled water $(1: 10 \mathrm{w} / \mathrm{v})$. Extraction then took place under cold conditions for $24 \mathrm{~h}$ (Rivillas-Acevedo and Soriano-Garcia, 2007).

Table 1

Wild medicinal plants used in the present study, collected from different locations of the Sinai Peninsula, Egypt and their bioactive compounds

\begin{tabular}{|c|c|c|c|}
\hline Scientific name & Family & Bioactive compounds & References \\
\hline $\begin{array}{l}\text { Asclepias sinaica } \\
\text { (Boiss.) Muschl }\end{array}$ & Asclepiadaceae & Imidacloprid, Levamisole, Pyrantel & $\begin{array}{l}\text { Semida et al., } \\
2006\end{array}$ \\
\hline $\begin{array}{l}\text { Farsetia aegyptia } \\
\text { Turra }\end{array}$ & Brassicaceae & $\begin{array}{l}\text { Flavonoid kaempferol-7, 8-diglucoside } \\
\text { kaempferol triosole }\end{array}$ & $\begin{array}{l}\text { Atta et al., } \\
2013\end{array}$ \\
\hline $\begin{array}{l}\text { Hypericum sinaicum } \\
\text { Hochst ex Boiss }\end{array}$ & Hypericaceae & $\begin{array}{l}\text { Hypercin, protohypericin, pseudohypericin, } \\
\text { hyperforin and proto pseudohypericin }\end{array}$ & $\begin{array}{l}\text { Alali et al., } \\
2009\end{array}$ \\
\hline $\begin{array}{l}\text { Phagnalon sinaicum } \\
\text { Bornm. and Kneucker }\end{array}$ & Asteraceae & Thmol, dammadienyl acetate, squalene, phytol & $\begin{array}{l}\text { El-Dahmy } \\
\text { et al., } 1994\end{array}$ \\
\hline Salvia aegyptiaca $\mathrm{L}$. & Lamiaceae & $\begin{array}{l}\text { 6-Methyleryptoacetalide, aegyptinones } \\
\text { A and B, 6-methyl-epicryptoacetalide, } \\
\text { 6-methylcryptotanshinone }\end{array}$ & $\begin{array}{l}\text { Al-Yousuf } \\
\text { et al., } 2002\end{array}$ \\
\hline
\end{tabular}


Plant extracts were filtered through two pieces of cheese cloths. Aqueous extract at a concentration of $10 \%$ (as an original concentration) and its 2 -fold dilution (5\%) were used in the antifungal activity experiments.

\section{Effect of plant extracts on linear mycelial growth}

The seed-borne fungi (Aspergillus flavus, Botrytis fabae, Fusarium oxysporum and Penicillium italicum) were used for antifungal activity of water extracts from different selected plants because these fungi were the most predominant species isolated from different broad bean cultivars. To every $15 \mathrm{ml}$ of sterile Potato Dextrose Agar (PDA) medium in Petri dishes, $5 \mathrm{ml}$ of each of the aqueous extract concentrations ( 5 and 10\%) from each plant were added. The solution in each Petri dish was gently swirled and allowed to solidify. The extract-amended medium in the Petri dishes were inoculated each alone at the center with $5 \mathrm{~mm}$ inoculum-disc of each test fungus and incubated at $25 \pm 2{ }^{\circ} \mathrm{C}$ for 7 days. Ridomil MZ fungicide produced by SYNGENTA Metalaxyl: $8 \%$ Methyl N-(methoxy acetyl)-N-(2, 6-xyly)-DL-alaninate; Mancozeb: 64\% Manganese ethylene_bis (dithiocarbamate)(polymeric) complex with zinc salt and $28 \%$ inactive matter as $72 \%$ wettable powder was used as a standard. The medium with the inoculum disc but without any extract served as the control.

\section{Effect of plant extracts on seed germination}

Non-treated and plant extract-treated seeds of broad bean cultivars were used for laboratory, and pot experiments for evaluation of plant extracts on seed germination and seedling vigor (root and shoot lengths of germinated seedlings). The water extract of Asclepias sinaica (the most effective for antifungal activity) was used. The seeds were separately soaked in water extracts for one hour and then plated on moist blotters as well as in a sterilised soil mix in pots. The untreated seeds were soaked in distilled water for one hour and plated on moist blotters and acted as the control. A total of 100 seeds were soaked per extract. Ten seeds were plated on a blotter per Petri dish. The extract-treated and untreated seeds were incubated at $20 \pm 2{ }^{\circ} \mathrm{C}$ for seven days. Seeds plated on a blotter were examined for fungal growth and percentage seed germination, after 7 days of incubation. The percentage of seedling emergence was recorded in seeds sown in the sterilised soil mix after 14 days.

For the soil experiment, 20 seeds were planted per pot equidistantly, at a depth of $2.0 \mathrm{~cm}$ and 5 pots were used per extract treatments. All tests were replicated five times. The germination was counted when the first leaf of the seedling reached a length of $4.0 \mathrm{~cm}$. The root and shoot lengths of germinated seedlings were also recorded.

\section{Greenhouse experiments}

Pathogenicity testing of predominant isolated fungi

Four predominant fungal pathogens (Aspergillus flavus, Botrytis fabae, Fusarium oxysporum and Penicillium italicum) were selected for health testing studies and evaluated for their pathogenicity on faba bean cultivars under greenhouse conditions. Inoculum 
from each of the above cultures was colonized on media consisting of crushed broad bean seed coats and peanut pod shells (1:1). Five hundred ml glass bottles, each containing $200 \mathrm{~g}$ of the media moistened with water, were autoclaved and the media inoculated with a $6 \mathrm{~mm}$ mycelial disk taken from a 7-day-old colony grown on PDA. The glass bottles were then incubated at $25 \pm{ }^{\circ} \mathrm{C}$ for 14 days.

Sandy clay (soil 1:2, w/w) was chemically sterilized using a 5\% formaldehyde solution. After treatment with formaldehyde, the soil was covered with boards or papers and left for $24 \mathrm{hrs}$, then allowed to dry until all odor of formaldehyde has disappeared from the soil. The soil then transferred into $15 \mathrm{~cm}$ diameter pots, each containing $3 \mathrm{~kg}$ soil. Pots were inoculated with the selected fungi growing in the seed coat-pod media separately at the rate of $5 \%(\mathrm{w} / \mathrm{w})$ and kept in the greenhouse for one week before sowing the faba bean seeds. Pots containing non-inoculated soil used as controls. Three replicates were used per treatment.

Pathogen-free seeds were surface sterilized and planted (5 seeds/pot) in both inoculated and non-inoculated soil. All pots were maintained in the greenhouse under natural conditions during winter season and watered as needed (El-Wakil et al., 2009). Fifteen days after sowing, the disease ratios were determined by recording the number of nonemerged seeds, while post-emergence and surviving plants were recorded 30 days after sowing. The equations described by Khalifa (1987) were followed:

Pre-emergence damping off $\%=$ No. of non-emerged seeds $/$ No. of sown seeds $\times 100$ Post-emergence damping off $\%=$ No. of dead seedlings $/$ No. of sown seeds $\times 100$

Surviving plants $\%=$ No. of surviving plants $/$ No. of sown seeds $\times 100$

\section{Inoculation of faba bean cultivars by Botrytis fabae}

Faba bean cultivars were infected by spraying $30 \mathrm{ml}$ of $B$. fabae (the most predominant fungus infecting faba bean cultivars) water spore suspension, containing $\left(2.5 \times 10^{6}\right.$ spores $\mathrm{ml}^{-1}$ ) with $1 \%$ Tween 80 by means of atomizer until the run-off point onto shoot of 30-day-old faba bean plants. Thereafter, plants in each pot were left to be air-dried, sprayed with $15 \mathrm{ml}$ distilled water and covered with plastic bags for two hours to maintain high humidity atmosphere around the leaves which is necessary for fungal infection.

\section{Application of aqueous extract of Asclepias sinaica on diseased faba bean cultivars}

Beacause aqueous extract of Asclepias sinaica at the concentration of $10 \%$ gave the strongest inhibitory effect on mycelial growth of predominant fungi, infected faba bean cultivars were exposed to three successive sprays within 15 days intervals by this extract. The positive control plants were sprayed only with $B$. fabae spore suspension without any treatment, or sprayed with Ridomil MZ fungicide $(250 \mathrm{~g} / 100 \mathrm{~L})$ while the negative control plants treated with the plant extract and left without any infection.

\section{Effect of aqueous extract of Asclepias sinaica on disease assessment}

Chocolate spot symptoms appeared 7 days after inoculation were scored as infection type and disease severity was assessed according to the 1-9 scale of Bernier et al. (1984). 
Disease severity $\%=(\mathrm{n} \times \mathrm{v}) / 9 \mathrm{~N} \times 100$

Where:

(n) = Number of plants in each category.

(v) = Numerical values of symptoms category.

$(\mathrm{N})=$ Total number of plants.

(9) = Maximum numerical value of symptom category.

Disease reduction $\%=$ Disease severity in control - Disease severity in treatment / Disease severity in control $\times 100$.

\section{Effect of aqueous extract of Asclepias sinaica on photosynthetic pigments}

Photosynthetic pigments (chlorophyll a, chlorophyll b and carotenoids) were determined according to the spectrophotometric method recommended by Metzner et al. (1965). One gm of fresh weight of plant leaves was cut in an ice cold porcelain mortar, some quartz sand was added and $100 \mathrm{mgs} \mathrm{Na}_{2} \mathrm{CO}_{3}$ powder were also used for reducing acidification. The leaves were ground with $80 \%$ acetone for 5 minutes. At the end of the grinding, the extract was stirred in the mortar, then quantitatively transferred to a centrifuge tube. The remaining pigments from the mortar was washed several times with cold $80 \%$ acetone and the volume completed to $8 \mathrm{ml}$, mixed well and the tube covered for the protection of the evaporation of acetone during the centrifugation.

The extract was centrifuged for $3 \mathrm{~min}$ at $1000 \mathrm{rpm}$. After centrifugation, the samples' colour was measured within a short time or the extracts were stored closed in a cold, dark place. The extract was measured against a blank of pure $80 \%$ aqueous acetone at 3 wave lengths of 480, 644 and $663 \mathrm{~nm}$ using Spectro UV-VIS RS spectrophotometer (Serial number: UV-VIS 0478; Labomed Inc. U.S.A). Taking into consideration the dilutions made, the concentrations of the pigment fractions (chlorophyll a, chlorophyll $\mathrm{b}$ and carotenoids) were calculated as $\mu \mathrm{g} / \mathrm{ml}$ using the following equations:

Chlorophyll a = 10.3 E663-0.918 E644 $\mu \mathrm{g} / \mathrm{ml}$

Chlorophyll $\mathrm{b}=19.7 \mathrm{E} 644-3.87 \mathrm{E} 663 \mu \mathrm{g} / \mathrm{ml}$

Carotenoids $=5.02 \mathrm{E} 480 \mu \mathrm{g} / \mathrm{ml}$

Then the fractions were calculated as $\mu \mathrm{g} / \mathrm{g}$ dry weight of the differently treated plant leaves.

\section{Effect of aqueous extract of Asclepias sinaica on total phenolics}

Total phenols were determined using the Folin-Ciocalteau reagent (Singleton and Rossi, 1965). For preparation of the calibration curve, $1 \mathrm{ml}$ aliquots of $0.02,0.04,0.06$, 0.08 and $1.00 \mathrm{mg} \mathrm{ml}^{-1}$ ethanolic catechol solutions were combined with $0.5 \mathrm{ml}$ FolinCiocalteau reagent. After $3 \mathrm{~min}, 2 \mathrm{ml}$ (200 g/l) sodium carbonate was added and the contents were mixed thoroughly. The final color change was measured colorimetrically at $650 \mathrm{~nm}$ using a SPEKOL 11 (Carl Zeiss, Jena, Germany).

Samples (2 g) of fresh leaves were homogenized in $80 \%$ aqueous ethanol at room temperature and centrifuged at 10,000 rpm for $15 \mathrm{~min}$ and the supernatant was saved. The residues were re-extracted twice with $80 \%$ ethanol and the supernatants were pooled, put 
in evaporating dishes and evaporated to dryness at room temperature. The residues in the evaporating dishes were dissolved in $5 \mathrm{ml}$ of distilled water. One hundred microliters of this extract was diluted to $3 \mathrm{ml}$ with distilled water and mixed with the same amount of reagent as described above. The colour was developed and absorbance measured after 60 $\mathrm{min}$. The results were expressed as $\mathrm{mg}$ catechol/100 $\mathrm{g}$ fresh weight material. All determinations were replicated three times. Total content of phenolic compounds in plant ethanolic extracts was calculated as catechol equivalents by the following equation:

$$
\mathrm{T}=\mathrm{C} \times \mathrm{V} / \mathrm{M}
$$

Where:

$\mathrm{T}=$ total content of phenolic compounds, in $\mathrm{mg} / \mathrm{g}$, in catechol equivalent.

$\mathrm{C}=$ concentration of catechol established from the calibration curve, in $\mathrm{mg} \mathrm{ml}^{-1}$.

$\mathrm{V}=$ volume of extract in $\mathrm{ml}$.

$\mathrm{M}=$ weight of pure plant ethanolic extract in $\mathrm{g}$.

Effect of aqueous extract of Asclepias sinaica on fruit yield

After harvest, number of pods per plant, number of seeds per pod, seed biomass, pod biomass and seed yield per plant were determined after the application of water plant extract.

\section{Statistical analysis}

The obtained results were statistically analysed according to Steel and Torrie (1980). LSD test was used to compare means of treatments at 5\% levels of significance.

\section{Results}

\section{Isolated fungi from seed cultivars}

Table 2 showed that 97 fungal colonies were identified from 100-100 broad bean seeds of cultivars. The identified fungal species contaminating the broad bean cultivars were Alternaria alternata, Aspergillus flavus, A. niger, Botrytis fabae, Cladosporium cladosporioides, Fusarium oxysporum, F. solani, Penicillium italicum, Rhizoctonia solani, Rhizopus stolonifer, Stemphylium globuliferum and Trichothecium roseum. Botrytis fabae, Aspergillus flavus, Fusarium oxysporum and Penecillium italicum were the predominant species $(5.0 \%, 3.75 \%, 3.0 \%$ and $2.5 . \%$, frequencies, respectively) and the least significant were Alternaria alternata, Aspergillus niger, Fusarium solani, Rhizoctonia solani, Rhizopus stolonifer and Stemphylium globuliferum (1.25\%) and Cladosporium cladosporioides $(0.75 \%)$. Misr 1 cultivar recorded the highest frequency of fungi $(7.0 \%)$ and the least was Giza $843(4.25 \%)$. These predominant fungal species were recorded from all faba bean cultivars, but the cultivar Misr 1 was infested by all isolated fungi (Table 2). 
Table 2

List of fungi isolated from different faba bean cultivars (400 seeds and 100 seeds of each cultivar)

\begin{tabular}{|c|c|c|c|c|c|c|}
\hline \multicolumn{7}{|c|}{ Cultivars } \\
\hline Fungal species & Giza 3 & Giza 429 & Giza 843 & Misr 1 & Incidence & $\%$ Frequency \\
\hline $\begin{array}{l}\text { Alternaria alternata } \\
\text { (Fr.) Keissler }\end{array}$ & 1 & 1 & 1 & 2 & 5 & 1.25 \\
\hline $\begin{array}{l}\text { Aspergillus flavus } \\
\text { (Link ex. Gray) }\end{array}$ & 4 & 4 & 2 & 5 & 15 & 3.75 \\
\hline $\begin{array}{l}\text { A. niger } \\
\text { (Van Tieghem) }\end{array}$ & 2 & - & 1 & 2 & 5 & 1.25 \\
\hline $\begin{array}{l}\text { Botrytis fabae } \\
\text { (Sardina) }\end{array}$ & 5 & 8 & 4 & 3 & 20 & 5.0 \\
\hline $\begin{array}{l}\text { Cladosporium cladosporioides } \\
\text { (Frensen. De Vries) }\end{array}$ & 2 & - & - & 1 & 3 & 0.75 \\
\hline $\begin{array}{l}\text { Fusarium oxysporum } \\
\text { (Schlechlendahl) }\end{array}$ & 4 & 1 & 2 & 5 & 12 & 3.0 \\
\hline $\begin{array}{l}\text { F. solani } \\
\text { (Mart.) Sacc. }\end{array}$ & - & 3 & - & 2 & 5 & 1.25 \\
\hline $\begin{array}{l}\text { Penicillium italicum } \\
\text { Wehmer }\end{array}$ & 4 & 3 & 2 & 1 & 10 & 2.5 \\
\hline $\begin{array}{l}\text { Rhizoctonia solani } \\
\text { (Kuhn) }\end{array}$ & 3 & - & 1 & 1 & 5 & 1.25 \\
\hline $\begin{array}{l}\text { Rhizopus stolonifer } \\
\text { (Ehr. ex Fr.) }\end{array}$ & - & 2 & 2 & 1 & 5 & 1.25 \\
\hline $\begin{array}{l}\text { Stemphylium globuliferum } \\
\text { (Vesterger.) E. G. Simmons }\end{array}$ & - & - & 1 & 4 & 5 & 1.25 \\
\hline $\begin{array}{l}\text { Trichothecium roseum } \\
\text { (Pers.) Link }\end{array}$ & 1 & 4 & 1 & 1 & 7 & 1.75 \\
\hline Total incidence & 26 & 27 & 17 & 28 & 97 & \\
\hline$\%$ Frequency & 6.5 & 6.75 & 4.25 & 7.0 & & \\
\hline
\end{tabular}

Effect of aqueous extracts on mycelial growth of predominant fungi

The efficacy of five aqueous extracts (5\% and 10\%) against the predominant isolated fungi (Aspergillus flavus, Botrytis fabae, Fusarium oxysporum and Penicillium italicum) of faba bean cultivars are shown in (Table 3). The aqueous extract of different medicinal plants exhibited varying levels of inhibition on mycelial growth of predominant fungi when compared with the control. The synthetic fungicide at 5\% and 10\% concentrations recorded a minimum growth inhibition on the fungi. At the both concentrations of the extracts used in this study, Asclepias sinaica was observed to have the highest inhibitory effects on the four fungi. However, the synthetic fungicide gave the highest percentage inhibition at the same levels of concentration. The mycelial growth of Penicillium italicum was found to be more strongly inhibited by the leaf extracts than growth of other fungal species. 


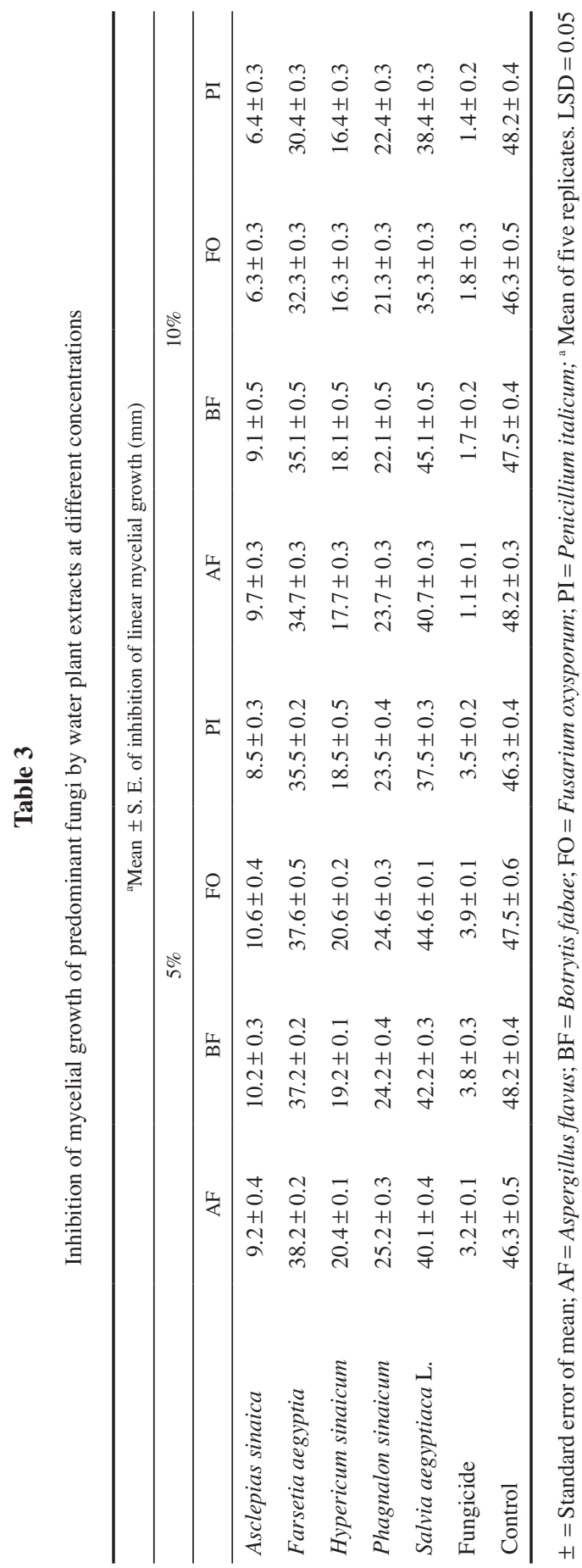

Acta Phytopathologica et Entomologica Hungarica 50, 2015 


\section{Effect of plant extracts on seed germination and seedling vigor}

Germination of non-treated broad bean seeds was low in pots (11.9\%-18.9\%) as compared to laboratory tests $(20.8 \%-27.5 \%)$ (Table 4$)$. In both experiments, in laboratory and pots, the maximum germination was recorded in Giza 843 (27.5\% and 18.9\%, respectively), whereas, Misr 1 showed minimum germination (20.8\% and $11.9 \%$, respectively). It was evident from these results that high infestation led to a minimum germination since the highest frequency of fungal contamination was recorded from the variety Misr 1 . On the other hand, plant extract of A. sinaica (10\%) increased seed germination and plant emergence of different cultivars. In both experiments, the maximum germination was recorded in Giza 843 (39.5\% and 25.1\%, respectively), whereas, Misr 1 showed minimum germination $(22.5 \%$ and $15.8 \%)$. The maximum root and shoot lengths were obtained in case of Giza 843 (4.2 and $9.1 \mathrm{~cm}$, respectively), whereas the minimum was obtained in case of Misr 1 (3.1 cm and $7.8 \mathrm{~cm}$, respectively). Treatment of seeds with A. sinaica extract led to an increase of root and shoot lengths. The maximum lengths were obtained in case of Giza $843(6.8 \mathrm{~cm}$ and $14.9 \mathrm{~cm}$, respectively), whereas the minimum lengths were obtained in case of Misr $1(5.1 \mathrm{~cm}$ and $12.1 \mathrm{~cm}$, respectively) (Table 5).

\section{Table 4}

The effect of Asclepias sinaica extract (at 10\% concentration) on seeds germination and plant emergence of 4 faba bean cultivars

\begin{tabular}{lcccc}
\hline \multirow{2}{*}{ Cultivars } & \multicolumn{2}{c}{ Non-treated } & \multicolumn{2}{c}{ Plant extract-treated } \\
\cline { 2 - 5 } & Seed germination $(\%)$ & Plant emergence $(\%)$ & Seed germination $(\%)$ & Plant emergence $(\%)$ \\
\hline Giza 3 & $22.8 \pm 1.2$ & $12.3 \pm 0.9$ & $32.2 \pm 2.1$ & $19.8 \pm 0.9$ \\
Giza 429 & $27.2 \pm 1.6$ & $17.6 \pm 0.6$ & $38.3 \pm 2.6$ & $22.9 \pm 0.9$ \\
Giza 843 & $27.5 \pm 1.1$ & $18.9 \pm 0.6$ & $39.5 \pm 2.9$ & $25.1 \pm 1.1$ \\
Misr 1 & $20.8 \pm 1.3$ & $11.9 \pm 0.4$ & $22.5 \pm 1.9$ & $15.8 \pm 0.7$ \\
\hline
\end{tabular}

$\mathrm{LSD}=0.05, \pm=$ Standard error of mean

Table 5

The effect of Asclepias sinaica extract (at $10 \%$ concentration) on root and shoot lengths of 4 faba bean cultivars seedlings

\begin{tabular}{lcccc}
\hline \multirow{2}{*}{ Cultivars } & \multicolumn{2}{c}{ Non-treated } & \multicolumn{2}{c}{ Plant extract-treated } \\
\cline { 2 - 5 } & Root length $(\mathrm{cm})$ & Shoot length $(\mathrm{cm})$ & Root length $(\mathrm{cm})$ & Shoot length $(\mathrm{cm})$ \\
\hline Giza 3 & $3.6 \pm 0.3$ & $8.7 \pm 0.5$ & $5.9 \pm 0.4$ & $12.5 \pm 0.5$ \\
Giza 429 & $3.8 \pm 0.2$ & $8.9 \pm 0.4$ & $6.5 \pm 0.2$ & $12.7 \pm 0.3$ \\
Giza 843 & $4.2 \pm 0.4$ & $9.1 \pm 0.2$ & $6.8 \pm 0.1$ & $14.9 \pm 0.2$ \\
Misr 1 & $3.1 \pm 0.1$ & $7.8 \pm 0.1$ & $5.1 \pm 0.5$ & $12.1 \pm 0.3$ \\
\hline
\end{tabular}

$\mathrm{LSD}=0.05, \pm=$ Standard error of mean 


\section{Pathogenicity testing of fungal isolates}

Results of the pathogenicity tests of of the predominant isolated fungi (Aspergillus flavus, Botrytis fabae, Fusarium oxysporum and Penicillium italicum) are shown in (Table 6). Disease severity readings of the fungi on seeds and seedlings were achieved after 15, 30 and 45 days after sowing. Botrytis fabae had the lowest percentage of pre-emergence damping-off among faba bean cultivars Giza 3, Giza 429, Giza 843 and Misr 1 . The percentage of infection was $14.82 \%, 10.50 \%, 6.32 \%$ and $8.40 \%$, respectively on seeds compared with the control treatment which had $0 \%$ infection. The same pathogen had also the lowest percentage of post-emergence damping-off among faba bean cultivars. The percentage of infection was $9.82 \%, 10.50 \%, 7.56 \%$ and $5.21 \%$, respectively on seeds compared with the control treatment which had $0 \%$ infection. On the other hand, the same pathogen exhibited the highest percentage of killed seedlings among all faba bean cultivars. The percentage of dead seedlings was $24.80 \%, 26.70 \%, 52.40 \%$ and $30.50 \%$, respectively for infected plants compared with the control treatment which showed $5.60 \%$ death. Moreover, B. fabae had the most adverse effect on all cultivars tested particulary for cultivar Giza 843.

\section{Effect of aqueous extract of A. sinaica on disease severity}

Disease severity (\%) of chocolate spot disease on faba bean cultivars in the greenhouse when treated with the $A$. sinaica extract (10\%) was shown in (Table 7). Data showed that the treatment significantly reduced the disease severity compared with the control treatment. Results indicated that the plant extract reduced the disease severity comparing with the pathogen (control) for Giza 3, Giza 429, Giza 843 and Misr 1 cultivars by $26.2 \%, 27.5 \%, 21.7 \%$ and $28.9 \%$, respectively. On the other hand, the plant extract reduced the disease severity comparing with pathogen + fungicide by $84.3 \%, 84.1 \%, 88.1 \%$ and $82.0 \%$, respectively. Generally, using of fungicide combined with the plant extract reduced the disease severity than fungicide or plant extract when they were used separately.

\section{Effect of aqueous extract of A. sinaica on photosynthetic pigments and total phenolics}

In relation to the untreated control plants, spraying of faba bean cultivars by $A$. sinaica extract led to an increase $(P \leq 0.05)$ of $\mathrm{chl} \mathrm{a}$, chl b and carotenoids of all cultivars when compared with those treated with pathogen alone, or pathogen and fungicide together. It seems that the combination of fungicide with the extract in the presence of the pathogen lead to an increase of total pigments when compared to fungicide with the pathogen (Tables 8, 9, 10 and 11). Giza 843 cultivar exihibited the highest $(P \leq 0.05)$ total pigments when the plant extract was used with the pathogen $\left(1.456 \mathrm{mg} \mathrm{g}^{-1} \mathrm{~d}\right.$ wt) or with pathogen and fungicide $\left(1.175 \mathrm{mg} \mathrm{g}^{-1} \mathrm{~d} \mathrm{wt}\right)$ when compared with the pathogen only (1.036 $\mathrm{mg} \mathrm{g}^{-1} \mathrm{~d}$ wt) (Table 10), while Misr 1 cultivar recorded the lowest values (Table 11). On the other hand, total phenolics were increased $(P \leq 0.05)$ in case of all cultivars after their treatment by plant extract when compared with the control (Tables 8, 9, 10 and 11). Giza 843 exhibited the highest value in case of the pathogen with the plant extract $\left(27.21 \mu \mathrm{g} \mathrm{g}^{-1}\right.$ 


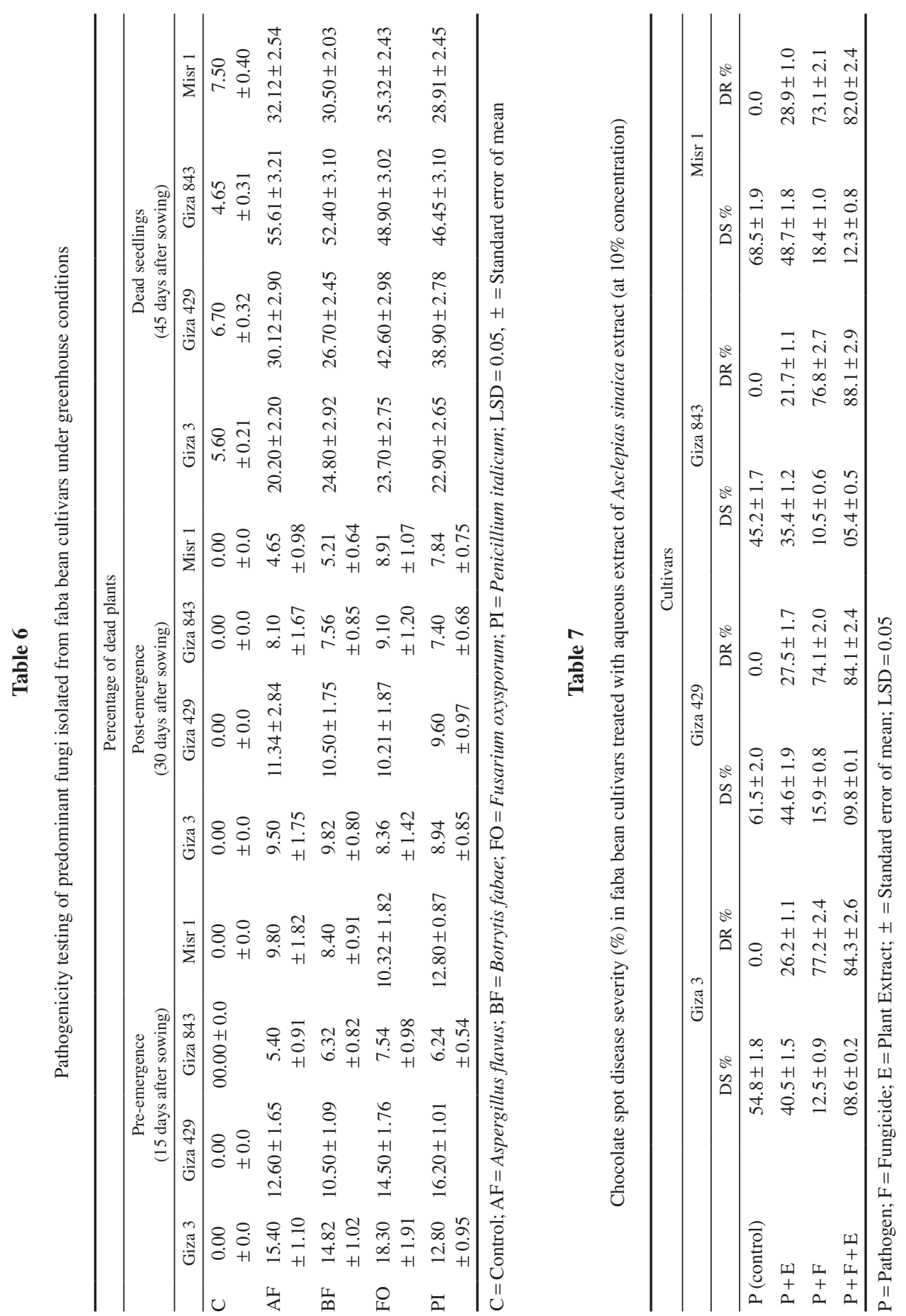


fresh wt) or pathogen and fungicide with the extract $\left(29.71 \mu \mathrm{g} \mathrm{g}^{-1}\right.$ fresh wt) (Table 10). Misr 1 cultivar recorded the lowest values (Table 11).

\section{Effect of aqueous extract of A. sinaica on fruit yield}

Effect of aqueous A. sinaica extract on fruit yield and yield components of faba bean cultivars is shown in (Tables $12,13,14$ and 15). In relation to control values, pathogen either alone or in the presence of fungicide caused drastic reduction $(P \leq 0.05)$ in all yield components of faba bean cultivars. Furthermore, pathogen alone caused an obvious decrease in yield components as compared to control plants. On the other hand, spraying of faba bean cultivars with the extract induced an increase $(P \leq 0.05)$ in nearly all yield components when compared with those treated with pathogen, or pathogen and fungicide.

\section{Table 8}

The effect of Asclepias sinaica extract (at $10 \%$ concentration) on photosynthetic pigments and total phenol contents of Giza 3 faba bean cultivar

\begin{tabular}{|c|c|c|c|c|c|}
\hline & \multicolumn{4}{|c|}{$\begin{array}{l}\text { Pigments content } \\
\left(\mathrm{mg} \mathrm{g}^{-1} \mathrm{~d} w \mathrm{t}\right)\end{array}$} & \multirow[t]{2}{*}{$\begin{array}{c}\text { Total phenol } \\
\left(\mu \mathrm{g} \mathrm{g}^{-1} \text { fresh wt) }\right.\end{array}$} \\
\hline & Chl a & Chl b & Carotenoids & Total pigments & \\
\hline $\mathrm{C}$ & $0.691 \pm 0.21$ & $0.231 \pm 0.06$ & $0.229 \pm 0.14$ & $1.153 \pm 0.07$ & $14.71 \pm 2.21$ \\
\hline $\mathrm{P}$ & $0.348 \pm 0.12$ & $0.148 \pm 0.06$ & $0.177 \pm 0.08$ & $0.773 \pm 1.06$ & $20.92 \pm 2.89$ \\
\hline $\mathrm{P}+\mathrm{E}$ & $0.592 \pm 0.20$ & $0.222 \pm 0.05$ & $0.218 \pm 0.12$ & $1.153 \pm 0.05$ & $22.21 \pm 3.01$ \\
\hline$P+F$ & $0.405 \pm 0.23$ & $0.175 \pm 0.04$ & $0.169 \pm 0.09$ & $0.869 \pm 0.81$ & $15.05 \pm 2.31$ \\
\hline$P+F+E$ & $0.528 \pm 0.19$ & $0.257 \pm 0.07$ & $0.289 \pm 0.11$ & $1.074 \pm 0.92$ & $26.70 \pm 2.92$ \\
\hline LSD at $P \leq 0.05$ & 0.014 & 0.008 & 0.007 & 0.013 & 1.44 \\
\hline
\end{tabular}

$\mathrm{C}=$ Control; $\mathrm{P}=$ Pathogen $\mathrm{F}=$ Fungicide $\mathrm{E}=$ Plant Extract $\pm=$ Standard error of mean

\section{Table 9}

The effect of Asclepias sinaica extract (at $10 \%$ concentration) on photosynthetic pigments and total phenol contents of Giza 429 faba bean cultivar

\begin{tabular}{lccccc}
\hline & & \multicolumn{2}{c}{$\begin{array}{c}\text { Pigments content } \\
\left(\mathrm{mg} \mathrm{g}^{-1} \mathrm{~d} \mathrm{wt}\right)\end{array}$} & $\begin{array}{c}\text { Total phenol } \\
\left(\mu \mathrm{g} \mathrm{g}^{-1} \text { fresh wt }\right)\end{array}$ \\
\hline $\mathrm{C}$ & Chl a & Chl b & Carotenoids & Total pigments & \\
$\mathrm{P}$ & $0.542 \pm 0.21$ & $0.245 \pm 0.10$ & $0.235 \pm 0.13$ & $1.022 \pm 1.08$ & $12.09 \pm 2.20$ \\
$\mathrm{P}+\mathrm{E}$ & $0.323 \pm 0.10$ & $0.139 \pm 0.04$ & $0.162 \pm 0.08$ & $0.624 \pm 1.07$ & $18.90 \pm 2.88$ \\
$\mathrm{P}+\mathrm{F}$ & $0.681 \pm 0.22$ & $0.261 \pm 0.07$ & $0.215 \pm 0.13$ & $1.157 \pm 0.07$ & $22.20 \pm 3.02$ \\
$\mathrm{P}+\mathrm{F}+\mathrm{E}$ & $0.413 \pm 0.23$ & $0.163 \pm 0.05$ & $0.173 \pm 0.09$ & $0.749 \pm 0.85$ & $15.05 \pm 2.31$ \\
$\mathrm{LSD}$ at $P \leq 0.05$ & $0.628 \pm 0.18$ & $0.287 \pm 0.08$ & $0.259 \pm 0.12$ & $1.174 \pm 0.98$ & $24.70 \pm 2.91$ \\
\hline
\end{tabular}

$\mathrm{C}=$ Control $; \mathrm{P}=$ Pathogen $; \mathrm{F}=$ Fungicide $; \mathrm{E}=$ Plant Extract $\pm \pm=$ Standard error of mean 
In majority of cases, A. sinaica extract combined with the fungicide caused additional increases in yield components of infected faba bean plants when compared with untreated infected plants. In general, cultivar G843 exhibited the highest yield components when treated with the extract, while Misr 1 gave the lowest productivity.

\section{Table 10}

The effect of Asclepias sinaica extract (at 10\% concentration) on photosynthetic pigments and total phenol contents of Giza 843 faba bean cultivar

\begin{tabular}{lccccc}
\hline & & \multicolumn{2}{c}{$\begin{array}{c}\text { Pigments content } \\
\left(\mathrm{mg} \mathrm{g}^{-1} \mathrm{~d} \mathrm{wt}\right)\end{array}$} & $\begin{array}{c}\text { Total phenol } \\
\left(\mu \mathrm{g} \mathrm{g}^{-1} \mathrm{fresh} w \mathrm{wt}\right)\end{array}$ \\
\hline $\mathrm{C}$ & $\mathrm{Chl} \mathrm{a}$ & \multicolumn{2}{c}{$\mathrm{Chl} \mathrm{b}$} & Carotenoids & Total pigments \\
$\mathrm{P}$ & $0.942 \pm 0.21$ & $0.358 \pm 0.11$ & $0.346 \pm 0.12$ & $1.646 \pm 1.08$ & $14.08 \pm 2.20$ \\
$\mathrm{P}+\mathrm{E}$ & $0.518 \pm 0.13$ & $0.247 \pm 0.06$ & $0.271 \pm 0.08$ & $1.036 \pm 1.07$ & $22.90 \pm 2.86$ \\
$\mathrm{P}+\mathrm{F}$ & $0.792 \pm 0.22$ & $0.335 \pm 0.08$ & $0.329 \pm 0.13$ & $1.456 \pm 0.07$ & $27.21 \pm 3.00$ \\
$\mathrm{P}+\mathrm{F}+\mathrm{E}$ & $0.613 \pm 0.20$ & $0.281 \pm 0.06$ & $0.281 \pm 0.07$ & $1.175 \pm 0.85$ & $18.05 \pm 2.31$ \\
$\mathrm{LSD}$ at $P \leq 0.05$ & 0.012 & 0.006 & $0.388 \pm 0.11$ & $1.474 \pm 0.98$ & $29.71 \pm 2.92$ \\
\hline
\end{tabular}

$\mathrm{C}=$ Control; $\mathrm{P}=$ Pathogen $; \mathrm{F}=$ Fungicide $; \mathrm{E}=$ Plant Extract $\pm=$ = Standard error of mean

Table 11

The effect of Asclepias sinaica extract (at 10\% concentration) on photosynthetic pigments and total phenol contents of Misr 1 faba bean cultivar

\begin{tabular}{|c|c|c|c|c|c|}
\hline & \multicolumn{4}{|c|}{$\begin{array}{l}\text { Pigments content } \\
\quad\left(\mathrm{mg} \mathrm{g}^{-1} \mathrm{dwt}\right)\end{array}$} & \multirow[t]{2}{*}{$\begin{array}{c}\text { Total phenol } \\
\left(\mu \mathrm{g} \mathrm{g}^{-1} \text { fresh wt) }\right.\end{array}$} \\
\hline & $\mathrm{Chl} \mathrm{a}$ & $\mathrm{Chl} \mathrm{b}$ & Carotenoids & Total pigments & \\
\hline $\mathrm{C}$ & $0.741 \pm 0.20$ & $0.244 \pm 0.12$ & $0.246 \pm 0.13$ & $1.231 \pm 1.08$ & $13.09 \pm 2.21$ \\
\hline $\mathrm{P}$ & $0.348 \pm 0.10$ & $0.148 \pm 0.05$ & $0.177 \pm 0.09$ & $0.773 \pm 1.07$ & $19.90 \pm 2.89$ \\
\hline$P+E$ & $0.691 \pm 0.21$ & $0.231 \pm 0.06$ & $0.229 \pm 0.14$ & $1.153 \pm 0.07$ & $23.20 \pm 3.01$ \\
\hline $\mathrm{P}+\mathrm{F}$ & $0.503 \pm 0.21$ & $0.183 \pm 0.07$ & $0.183 \pm 0.08$ & $0.869 \pm 0.85$ & $16.05 \pm 2.32$ \\
\hline $\mathrm{P}+\mathrm{F}+\mathrm{E}$ & $0.628 \pm 0.18$ & $0.257 \pm 0.08$ & $0.289 \pm 0.12$ & $1.174 \pm 0.98$ & $25.70 \pm 2.90$ \\
\hline LSD at $P \leq 0.05$ & 0.010 & 0.005 & 0.006 & 0.012 & 1.42 \\
\hline
\end{tabular}

$\mathrm{C}=$ Control $; \mathrm{P}=$ Pathogen $; \mathrm{F}=$ Fungicide $; \mathrm{E}=$ Plant Extract $\pm=$ Standard error of mean 


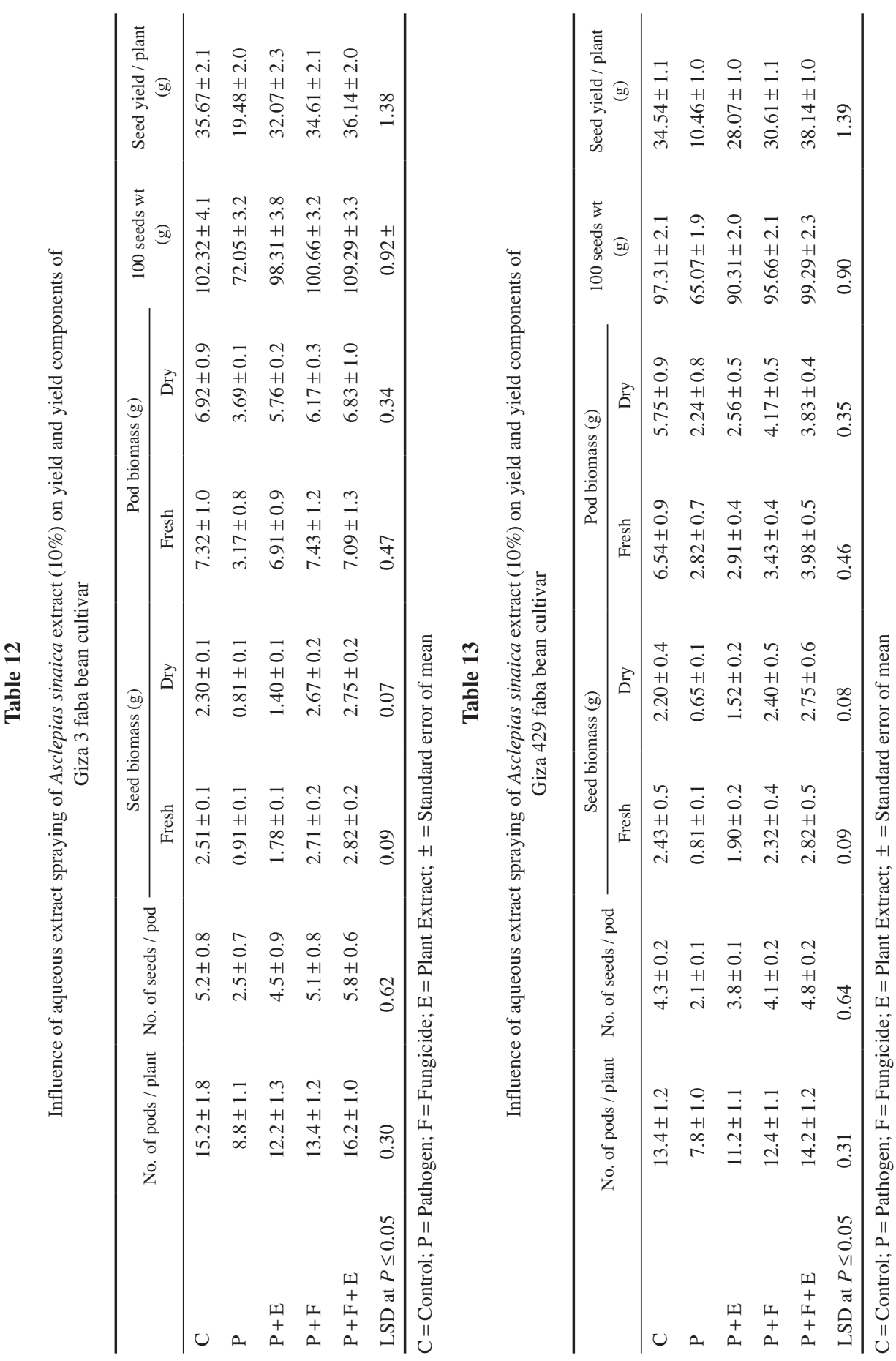




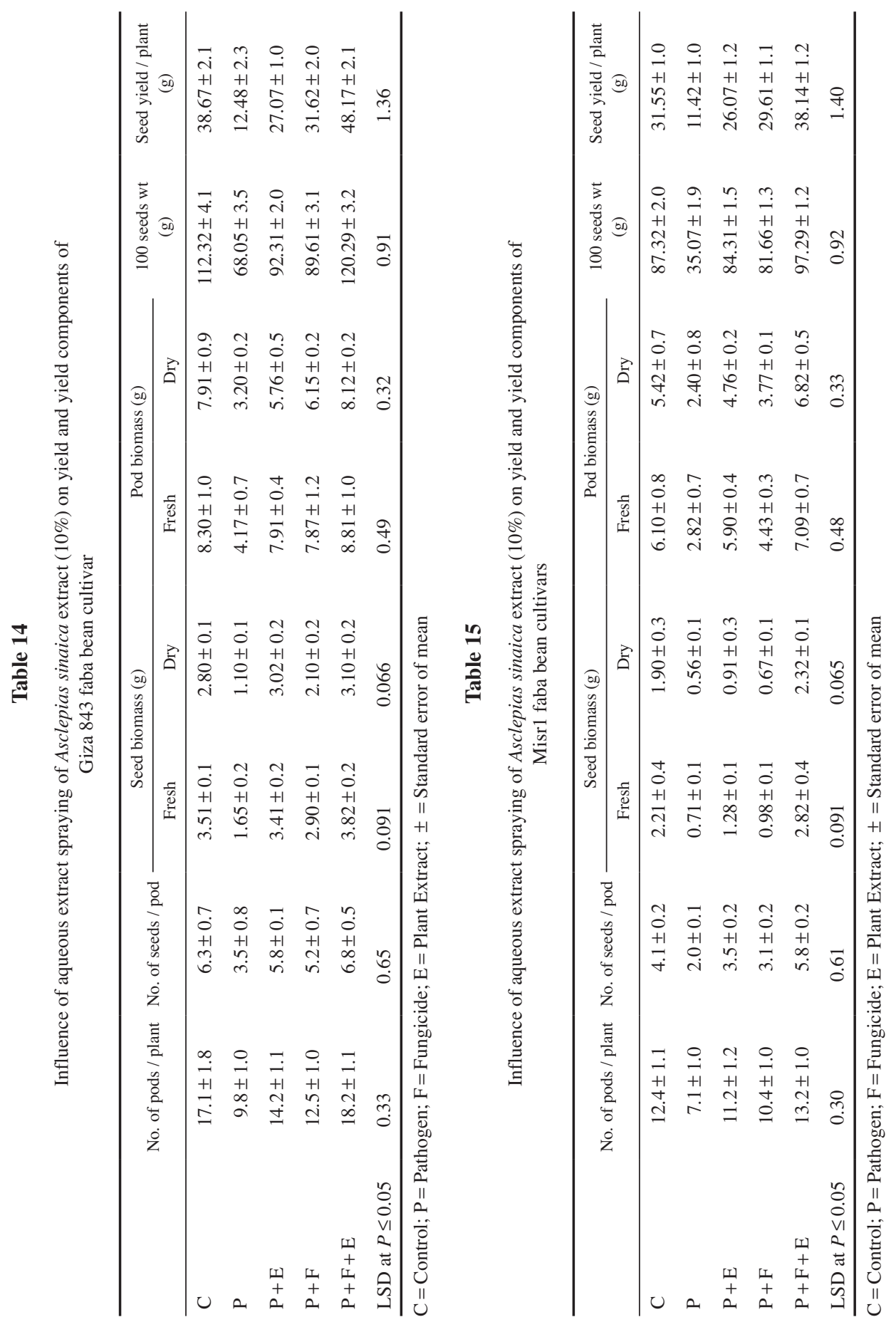

Acta Phytopathologica et Entomologica Hungarica 50, 2015 


\section{Discussion}

Plant extracts can contain natural antimicrobial compounds, and these can be used for seed disinfection as an alternative to fungicide treatments. Use of plant extracts against plant pathogenic fungi and plant diseases is relatively a recent approach. All plant extracts tested exhibited different degrees of antifungal activity against the predominant isolated fungi from different seeds of faba bean cultivars. The inhibitory effect of the tested extracts might be due to natural bioactive materials present in these extracts (El-Dahmy et al., 1994; Al Yousuf et al., 2002; Semida et al., 2006; Alali et al., 2009; Atta et al., 2013). Treated seeds of faba bean cultivars with these plant extracts led to a pronounced increase in seed germination and seedling vigor. These results are in agreement with those obtained by many authors (Hassan et al., 2005; Perello et al., 2013; Santos Júnior et al., 2014; Baka, 2014b) who reported that plant extracts can be used to enhance the germination of seeds and seedling vigor. The ability of the extracts to increase seed germination and seedling emergence could be attributed to the suppression of the incidence of the seed borne fungi that could have killed the embryo of the seeds.

Asclepias sinaica extract gave the best results to reduce the mycelial growth of predominant fungi infested faba bean seed cultivars in the laboratory experiments and also reduced disease severity of chocolate spot disease caused by Botrytis fabae in the greenhouse application. Baka (2014 a, b) reported that aqueous extract of A. sinaica gave the highest antifungal activity against the phytopathogen, Phytophthora infestans and fungi infested wheat grains. Such activity may be due to the presence of milky latex containing bitter and toxic alkaloids (Elbanna, 2007). Many authors believe that latex produced from the members of Asclepiadaceae contains many bioactive components which can be used as antimicrobials (Neenah, 2013). Such results are in accordance with pervious work on the role of extracts of medicinal plants in fungal diseases control which provided successful control against this disease in laboratory and greenhouse tests (Heweidy et al., 1997; Mahmoud et al., 2004; El-Metwally et al., 2010). The efficacy of medicinal plant species may be due to induction of the resistance mechanisms in treated plants (Yamunarani et al., 2004) or cause a delay in the development of infection in early growth stage by inhibition the mycelial growth of pathogen (Krebs and Forrer, 2001).

Pathogenicity tests showed that Aspergillus flavus, Botrytis fabae, Fusarium oxysporum and Penicillium italicum were the most pathogenic fungi isolated from faba bean cultivars which showed seed decay, pre-emergence damping-off and post-emergence damping-off. The most common fungi isolated from faba bean as reported by Abdel-Hafez (1988) and El-Wakil et al. (2009) were more or less different from those in isolated during the present investigation. This may be due to the variation of faba bean cultivars or the conditions of storage.

It is well known that photosynthetic pigments are a good parameter reflecting the health condition of any plant. It is evident from the present study that, infection with $B$. fabae significantly reduced the content of photosynthetic pigments in the leaves of faba bean plants. This reduction may be due to the effect of pathogen on the chloroplasts or on chlorophyll content directly or on the enzymes concerned with photosynthesis (Baka and Aldesuquy, 1992) and may be due to lipid peroxidation mediating cell damage in faba 
bean tissues (El-Khallal, 2007). Furthermore, Baka and Aldesuquy (1992) suggested that the marked depletion in chlorophyll content of infected squash leaves was attributed to the changes in ultrastructure of infected chloroplast and senescence of infected tissue. Torres et al. (2004) reported that the chocolate spot disease caused by Botrytis fabae is one of the most economically important diseases that damage the foliage, limit photosynthesis activity, and reduce faba bean production globally. On the other hand, total pigment content has considerably increased in all treated plants by plant extract of A. sinaica compared with non-sprayed plants. These results are in agreement of those of Mahmoud et al. (2004) and El-Metwally et al. (2010) who reported that plant extracts increased the photosynthetic activity of faba bean inoculated with Botrytis fabae. The stimulative effect of plant extracts on pigments biosynthesis might presumably due to the fact that these extracts increase the rate of transpiration and this will possibly increase the rate of translocation of minerals and cytokinins from root to developing shoot. From another point of view, plant extracts may delay the senescence of the plant by retaining the chlorophyll, improve the growth parameter of the plant by increasing turgidity, stimulating leaf expansion, enhancing the production of photosynthetic pigments and increase yield capacity of the plant (Baka and Aldesuquy, 1992). The increase in photosynthetic pigments led to carbohydrates accumulation, hence increase carbohydrate contents in faba bean plants. Carbohydrates are the main repository of photosynthetic energy, they comprise structural polysaccharides of plant cell walls and principally cellulose, hemicellulose and pectin, also associated with the structural polysaccharides are phenolic compounds, which play an important role in plant defense such phenols that are essential for biosynthesis of lignin, which is considered an important structural component of plant cell walls (Hahlbrock and Scheel, 1989).

Moreover, the present results indicated that the tested medicinal plant extract increased the levels of total phenolics. These results are in agreement with those reported by some authors (Vermerris and Nicholson, 2008; Mikulič-Petkovšek et al., 2009; Baka et al., 2013). This increase in total phenol may have attributed to increase in the defense capability of plants to infection disease and development. The toxic phenolic compounds in plant cells were found to be act through: (1) the structure of bond form with cell wall components of plant tissues (Mahadevant and Sridhar, 1986), (2) enhance host resistant by stimulating host defense mechanisms (Subba Rao et al., 1988), (3) prevent the spread of fungal growth in plant tissues (Soni et al., 1992) and (4) penetrate the microorganisms and cause considerable damage to the cell metabolism (Kalaichelvan and Elangovan, 1995).

Phenols have been recorded to offer resistance to diseases and pests in plants, and seeds containing high amount of polyphenols are resistant to several plant diseases (Malik and Singh, 1980). There were many researchers established that higher level of phenolic content was positively proportional to the degree of plant resistance against various fungal diseases (Ramamoorthy et al., 2002; Abo-Elyousr et al., 2009). It is well known that synthesis of phenols occurs as an early response of plants to attempt infection by pathogens, as antimicrobial compounds, signal molecules, and cell wall strengthening components (Kruger et al., 2002). 


\section{Literature}

Abdel-Hafez, A. I. I. (1988): Mycoflora of broad bean, chickpea and lentil seeds in Egypt. Cryptogamie Mycologie 9, 343-355.

Abo-Elyousr, K. A. M., Hashem, M. and Ali, E. H. (2009): Integrated control of cotton root rot disease by mixing fungal biocontrol agents and resistance inducers. Crop Protection 28, 295-301.

Alali, F. Q., Tawaha, K. and Gharaibeh, M. (2009): LC-MS and LC-PDA analysis of Hypericum empetrifolium and Hypericum sinaicum. Zeitschrift für Naturforschung C 64, 476-482.

Al Yousuf, M. H., Bashir, A. K., Blunden, G., Crabb, T. A. and Patel, A. A. (2002): 6-methylcryptoacetalide, 6-methyl-epicryptoacetalide and 6-methylcryptotanshinone from Salvia aegyptiaca. Phytochemistry 61, 361-365.

Ammar, M. I., Nenaah, G. E. and Mohamed, A. H. (2013). Antifungal activity of prenylated flavonoids isolated from Tephrosia apollinea $\mathrm{L}$. against four phytopathogenic fungi. Crop Protection, 49, 21-25.

Atta, E. M., Hashem, A. I. and Eman, R. E. S. (2013): A novel flavonoid compound from Farsetia aegyptia and its antimicrobial activity. Chememical and Natural Compounds 49, 432-436.

Baka, Z. A. M. (2014a): Antifungal activity of extracts from five Egyptian wild medicinal plants against late blight disease of tomato. Archives of Phytopathology and Plant Protection 47, 1988-2002.

Baka, Z. A. M. (2014b): Plant extract control of the fungi associated with different Egyptian wheat cultivars grains. J. Plant Protection Research 54, 231-237.

Baka, Z. A. M. and Aldesuquy, H. S. (1992): Studies on powdery mildew fungus Spherotheca fuliginea: Ultrastructure and host responses. Acta Botanica Hung. 37, 15-31.

Baka, Z., ElAzab, N. and Aldesuquy, H. (2013): Biocontrol of Chocolate Spot Disease of Faba Bean: Phenolic Compounds as Resistant Inducers. LAP Lambert Academic Publishing, AV Akademikerverlag GmbH and Co. KG, Saarbrücken, Germany, 168 p.

Barnett, H. L. and Hunter, B. B. (1972): Illustrated Genera of Imperfect Fungi ( ${ }^{\text {rd }}$ ed.), Burgess Publish Co, Minnesota, USA, $24 \mathrm{p}$.

Bernier, C. C., Hanounik, S. B., Hussein, M. M. and Mohamed, H. A. (1984): Rating scale for faba bean diseases in Nile valley. ICARDA Information Bulletin No. 3, $37 \mathrm{p}$.

Booth, C. (1971): The Genus Fusarium. Commonwealth Mycological Institute, Kew, Surrey, England, 237 p.

Elbanna, S. M. (2007): Insect interactions of three trophic levels on milkweed plant Asclepias sinaica (Boiss.) Musch. International J. of Agriculture and Biology 9, 291-293.

El-Dahmy, S. I., Abdel Aal, M., Abd el-Fatah, H. and Fid, F. (1994): Thymol derivatives from Phagnalon sinaicum Bornm. and Kneuck. Acta Pharmaceutica Hung. 64, 115-116.

El-Khallal, S. M. (2007): Induction and modulation of resistance in tomato plants against Fusarium wilt disease by bioagent fungi (Arbuscular Mycorrhiza) and/or hormonal elicitors (jasmonic acid and salicylic acid): 2-Changes in the antioxidant enzymes, phenolic compounds and pathogen related proteins. Australian J. of Basic and Applied Sciences 1, 717-732.

El-Metwally, M. A., Ghanem, K. M. and Abd El-Hai, K. M. (2010): Improving the performance of faba bean and controlling of chocolate spot disease using bio-compounds. Plant Pathology J. 9, 169-178.

El-Wakil, M. A., El-Refai, I. M., Awadallah, M. A., El-Metwally, M. A. and Mohammed, M. S. (2009): Seedborne pathogens of faba bean in Egypt: Detection and pathogencity. Plant Pathology J. 8, 90-97.

Hahlbrock, K. and Scheel, D. (1989): Physiology and molecular biology of phenyl propanoid metabolism. Annual Rev. of Plant Physiol. and Plant Molecular Biol. 40, 347-369.

Hasan, M. M., Chowdhury, S. P., Alam S., Hossain, B. and Alam, M. S. (2005): Antifungal effects of plant extracts on seedborne fungi of wheat seed regarding seed germination, seedling health and vigour index. Pakistan J. of Biological Sciences 8, 1284-1289.

Heweidy, M. A. M. and Mahmoud F. A. F. (1997): The use of crude extracts of garlic cloves and henna leaves as a biological control against chocolate spot disease of faba bean. $8^{\text {th }}$ Congress of Egyptian Phytopathological Society, Cairo, Egypt, pp. 161-171.

Jackson, C. R. (1963): Small-plot evaluation of seed treatment fungicides for control of Aspergillus crown rot of peanut. Plant Disease Reporter 47, 147-150. 
Kalaichelvan, P. T. and Elangovan, N. (1995): Effect of phenolics on Drechslera oryzae. Indian Phytopathol. 48, 271-274.

Khalifa, E. Z. (1987): Further studies on some soil borne fungi affecting soybean and their control. PhD thesis, Faculty of Agriculture, Menouifya University, Egypt, 148 p.

Khlangwiset, P., Shephard, G. S. and Wu, F. (2011): Aflatoxins and growth impairment. Critical Reviews in Toxicology 41, 740-755.

Krebs, H. and Forrer, H. R. (2001): Potatoes: effects of incorporation of medicinal plants into soil. Agrarforschung 8, 470-475.

Kruger, W. M., Carver, T. W. and Zeyen, R. J. (2002): Phenolic inhibition of penetration resistance to Blumeria graminis $\mathrm{f}$. sp. hordei in barley near isogenic lines containing seven independent resistance genes or alleles. Physiol. and Molecular Plant Pathol. 61, 41-51.

Mahadevant, A. and Sridhar K. (1986): Methods of Physiological Plant Pathology. $3^{\text {rd }}$ ed. Sivakami Pub. Madras, India, pp. 1-328.

Mahmoud, Y. A. G., Ebrahim, M. K. H. and Aly, M. M. (2004): Influence of some plant extracts and microbioagents on some physiological traits of faba bean infected with Botrytis fabae. Turkish J. of Botany 28, 519-528.

Malik, C. P. and Singh, M. B. (1980): Estimation of Total Phenols in Plant Enzymology and Histo-Enzymology. Kalyani Publishers, New Delhi, pp. 1-286.

Mancini, V. and Romanazzi, G. (2014): Seed treatments to control seedborne fungal pathogens of vegetable crops. Pest Management Sci. 70, 860-868.

Mathur, S. B. and Kongsdal, O. (2003): Common Laboratory Seed Health Testing Methods for Detecting Fungi. International Seed Testing Association, Bassersdorf, Switzerland.

Metzner, H., Rau, H. and Senger, H. (1965): Untersuchungen zur Synchronisierbarkeit einzelner Pigmentmangel-Mutanten von Chlorella. Planta 65, 186-194.

Mikulič-Petkovšek, M., Štampar, F. and Veberič, R. (2009): Accumulation of phenolic compounds in apple in response to infection by the scab pathogen, Venturia inaequalis. Physiol. and Molecular Plant Pathol. 74, 60-67.

Neenah, G. (2013): Antimicrobial activity of Calotropis procera Ait. (Asclepiadaceae) and isolation of four flavonoid glycosides as the active constituents. World J. of Microbiology and Biotechnology 29, 1255-1262.

Neergard, P. (1979): Seed Pathology. The Macmillan Press Ltd., London., pp. 1-1187.

Pal, K. K. and Gardener, B. M. (2006): Biological control of plant pathogens. The Plant Health Instructor, DOI: 10.1094/PHI-A 1117-02.

Perello, A., Gruhlke, M., Alan, J. and Slusarenko, A. J. (2013): Effect of garlic extract on seed germination, seedling health, and vigor of pathogen-infested wheat. J. of Plant Protection Research 53, 317-323.

Ramamoorthy, V., Raguchander, T. and Samiyappan, R. (2002): Induction of defense related proteins in tomato roots treated with Pseudomonas fluorescens Pf1 and Fusarium oxysporum f. sp. lycopersici. Plant and Soil 239, 55-68.

Raper, K. B. and Fennell, D. I. (1977): The Genus Aspergillus. Robert EK Publish. Co., Huntington, New York, USA, pp. 1-68.

Rivillas-Acevedo, L. and Soriano-García, M. (2007): Antifungal activity of a protean extract from Amaranthus hypochondriacus seeds. J. of Mexican Chemical Society 51, 136-140.

Salunkhe, D. K. and Kadam, S. S. (1989): Handbook of World Food Legumes: Nutrition Chemistry, Processing Technology and Utilization. CRC Press, Inc. Boca Rotan, Florida, pp. 1-310.

Santos, Jr. H. M., Campos, V. A. C., Alves, D. S., Cavalheiro, A. J., Souza, L. P., Botelho, D. M. S., Chalfoun, S. M. and Oliveira, D. F. (2014): Antifungal activity of flavonoids from Heteropterys byrsonimifolia and a commercial source against Aspergillus ochraceus: In silico interactions of these compounds with a protein kinase. Crop Protection 62, 107-114.

Semida, F. M., El-Banna, S. M., Zalat, S. M. and Gilbert, F. S. (2006): Insect-plant interaction (Paramecops sinaitus/Asclepias) in Sinai ecosystem. J. of Egyptian Academic Society for Environmental Development 7, 173-183. 
Singleton, V. L. and Rossi, J. A. (1965): Colorimetry of total phenolics with phosphomolybdic-phosphotungstic acid reagents. American J. of Enology and Viticulture 16, 144-158.

Soni, G. L., Sedha, R. K., Khanna, P. K. and Garcha, H. S. (1992): Growth inhibition of Fusarium oxysprum by phenolic compounds. Indian J. of Microbiology 32, 45-49.

Steel, R. G. D. and Torrie, T. H. (1980): Principles and Procedures of Statistics. McGraw-Hill Book, New York, pp. 1-862.

Subba Rao, P. V., Geigen, J. P., Einhorn, J., Rio, B., Malosse, C., Nicole, M., Savary, S. and Ravise, A. (1988): Host defense mechanisms against groundnut rust. International Arachis Newsletter 4, 16-18.

Torres, A. M., Roman, B., Avila, C. M., Satovic, Z., Rubiales, D., Sillero, J. C., Cubero, J. L. and Moreno, M. T. (2004): Faba bean breeding for resistance against biotic stresses: towards application of marker technology. Euphytica 147, 67-80.

Vermerris, W. and Nicholson, R. (2008): Phenolic compound biochemistry. Springer Science Business Media B.V., Dordrecht, pp. 1-276.

Wang, J., Liu, H. and Ren, G. (2014): Near-infrared spectroscopy (NIRS) evaluation and regional analysis of Chinese faba bean (Vicia faba L.). The Crop J. 2, 28-37.

Yamunarani, K., Jaganathan, R., Bhaskaran, R., Govindaraju, P. and Velazhahan R. (2004): Induction of early blight resistance in tomato by Quercus infectoria gall extract in association with accumulation of phenolics and defense-related enzymes. Acta Physiol. Plantarum 26, 281-290.

Yoon, M. Y., Choi, G. J., Choi, Y. H., Jang, K. S., Cha, B. and Kim, J. C. (2011): Antifungal activity of polyacetylenes isolated from Cirsium japonicum roots against various phytopathogenic fungi. Industrial Crops and Products 34, 882-887. 